\title{
FUNCTIONAL PROPERTIES OF CASEIN ADDED WITH CATECHIN EXTRACTED FROM COCOA HUSK
}

\author{
Premy Puspitawati Rahayu, Djalal Rosyidi*, Purwadi and Imam Thohari \\ Animal Product Technology Department, Faculty of Animal Science, University of Brawijaya Jl. Veteran, \\ Malang, 65145, East Java, Indonesia \\ *Corresponding author: djalal_tht@ub.ac.id
}

Accepted 29 August 2019; Revised 12 September 2019

Published 17 October 2019

\begin{abstract}
Casein is one of the major protein components in milk. Its functional properties allow casein to be preferred by the consumers. In addition, casein could be collected as bioactive compositions to be added to food. The purpose of this study was to observe the functional properties of casein added with catechin from cocoa husk in terms of emulsions, emulsion activity, foaming, solubility, and sedimentation. The treatment was carried out by using a completely randomized experimental design (CRD) method with five treatments of different catechin concentrations (control; $0.5 \% ; 1,0 \% ; 1,5 \% ; 2 \%$ ). The results of the study were analyzed with analysis of variance and followed with least significant difference (LSD) test. The different catechin concentrations gave a highly significant effect on emulsion stability, foaming and sedimentation and gave no a significant difference in solubility and emulsion activity between the five treatments. The best treatment in this research was at $2 \%$ catechin addition.
\end{abstract}

Keywords: Emulsion stability; emulsion activity; sedimentation; solubility. 


\section{INTRODUCTION}

Casein is one of milk protein which accounted for $80 \%$ of total milk protein. The functional properties of casein include emulsion, foaming and a carrier vehicle for a bioactive compound that will be added in the product. These functional characteristics cause casein to be used in food (Lemes et al., 2010; Giroux et al., 2016). Casein acts as a delivery system for delivering materials that are essential for food (Ranadheera et al., 2016; Bonnaillie et al., 2014). This essential material can come from bioactive compounds in plants that have many health benefits. There are various bioactive compounds contained in nature, one of which is polyphenols, such as catechins, xanthone, curcumin, and others. The cocoa husk is a waste from cocoa products that are still underutilized.

To increase its value, cocoa husk can be used as a source of catechins. Catechins have many benefits including being able to reduce the risk of heart disease, hypertension, depression, anti-carcinogenic, antimicrobial, anti-inflammatory and arthritis (Shahidi and Miraliakbar, 2005; Jalil and Ismali, 2008; Rusconi and Conti, 2010; Ali et al., 2010; Ali et al., 2015). However, the addition of catechin required a delivering system (Lemes et al., 2010). Casein can be utilized in this process with the aim to simplify catechins addition process to be applied in food products. Several studies explained the bonds formed between proteins and polyphenols. Strauss and Gibson (2004) explained that milk protein can bind the phenolic compounds to form covalent bonds of $\mathrm{C}-\mathrm{N}$ or $\mathrm{C}-\mathrm{S}$ with phenol rings. Polyphenols can interact with milk to improve its functional properties. Proteins interaction with phenols can cause van der Waals, hydrogen and hydrophobic interactions (O'Connell and Fox, 2001). Based on these explanations, it can be concluded that casein can be used as a catechin carrier.

Apart from that, the nature of casein emulsion can stabilize the mixture of ingredients during the processing (Giroux et al., 2016; McClements et al., 2007). Casein froth can produce a good protective layer against oxidation, therefore, it can protect the material from oxidation reactions (Bonnaillie et al., 2014). The characteristic of an emulsion can be seen by calculating the emulsion's stability and its emulsion activity. Foaming capacity is determined by the percentage of froth on the ingredients. Emulsion stability is the ability of casein to maintain the emulsion that is formed to remain stable, while the activity of the emulsion is the ability of casein when forming the emulsion. Foaming capacity is the ability of casein to produce foaming after homogenization of the material (Estiasih et al., 2016; Sablovic et al., 2013, Al-Awwaly et al., 2015; Rahayu et al., 2015). Based on this, research should be done to determine the nature of the emulsion, foaming capacity, solubility, and casein sedimentation when given the addition of catechins with different concentration treatments.

\section{MATERIALS AND METHODS}

\section{Materials}

The material used in the study includes catechins extracted from cocoa shells, casein (TCI), $\mathrm{K}_{2} \mathrm{HPO}_{4}$ and $\mathrm{KH}_{2} \mathrm{PO}_{4}$ for the producing of $\mathrm{pH} 7$ buffer phosphate, soybean oil, and aquadest. The equipment used included analytical balance (HR-300), Ultra Turrax, Spectrophotometer (UV$1201 \mathrm{v}$, Shimadzu), rotary evaporator (Buchi), and filter paper (Whatman No. 1).
*Corresponding author:

Djalal Rosyidi

Email: djalal tht@ub.ac.id

Animal Product Technology Department, Faculty of Animal Science, University of Brawijaya Jl. Veteran, Malang, 65145, East Java, Indonesia
How to cite:

Rahayu, P. P., Rosyidi, D., Purwadi., \& Thohari, I. (2019). Functional Properties of Casein Added with Catechin Extracted from Cocoa Husk. Jurnal Ilmu dan Teknologi Hasil Ternak, 14 (2), 127-136 


\section{Research method}

This study used a laboratory experiment method with a completely randomized design and four replications. The addition of catechins in casein consists of five different treatments (control; $0.5 \%$; $1.0 \% ; 1.5 \% ; 2 \%)(\mathrm{w} / \mathrm{v})$.

\section{Cocoa husk extraction}

The cocoa husk extraction refers to Rahayu et al. (2015) with modification. Extraction was done by MicrowaveAssisted Extraction (MAE) method using a microwave (Sharp Model R-222y (S)) with a temperature of $70^{\circ} \mathrm{C}$. The cocoa husk powder was weighed for 3 gram and added with $100 \mathrm{~mL}$ of $96 \%$ ethanol and then stirred for $10 \mathrm{~min}$. The solution was extracted in the microwave for $4 \mathrm{~min}$ and then cooled and filtered in Whatman paper no 1. After that, the solvent is separated using a rotary evaporator until a catechin extract is obtained. The extract is then put inside a dark bottle and stored at $4^{\circ} \mathrm{C}$.

\section{Process of casein interaction with bioactive compounds from cocoa skin}

The processing of the casein solution begins by adding $10 \%$ casein in a $250 \mathrm{~mL}$ beaker glass containing $100 \mathrm{~mL}$ phosphate buffer. Catechins are added according to the treatment and homogenized by using Ultra Turrax at the speed of 7,600 rpm for $10 \mathrm{~min}$, under a solution temperature of $50^{\circ} \mathrm{C}$. Casein solution can be stored in a refrigerator at $4^{\circ} \mathrm{C}$. Furthermore, an analysis is carried out to determine the functional properties of casein including emulsion stability, emulsions activity, solubility, foaming, and sedimentation.

\section{Emulsion stability and activity}

Emulsion stability and activity were tested according to the method of Rahayu et al. (2015) with modifications. Samples to be tested were added with soybean oil and then stirred using a hand mixer for 1 minute. As much as $0.1 \mathrm{~mL}$ of the sample and $0.1 \%$ of SDS as much as $10 \mathrm{~mL}$ and stirred using vortex for 10 seconds. Afterward, about $3 \mathrm{~mL}$ of sample was taken and put in a cuvette and tested using a spectrophotometer with a wavelength of $500 \mathrm{~nm}$ and the absorbance value (A0) was recorded. After that, the emulsion process waited for $10 \mathrm{~min}$ and a similar test (A10) is performed. The resulting dispersion is measured by the formula:

$$
\text { Emulsion stability }(\%)=\frac{A_{10}}{A_{0}} x 100
$$

Description:

$\mathrm{A}_{0} \quad=\mathrm{A}_{500}$ at time of $0 \mathrm{~min} \quad \mathrm{~A}_{10} \quad=\mathrm{A}_{500}$ at time of $10 \mathrm{~min}$

Description:

$$
\begin{array}{ll}
\mathrm{A} & =\mathrm{A} 500 \\
\mathrm{DF} & =\text { Dilute factor }(100) \\
\mathrm{I} & =\text { Length of cuvette path }(\mathrm{m})
\end{array}
$$$$
\text { Emulsion activity }\left(\frac{\mathrm{m}^{2}}{\mathrm{~g}}\right)=\frac{2 \times 2.303 \times \mathrm{A} \times \mathrm{DF}}{\mathrm{I} \times \phi \times \mathrm{C}}
$$

\section{Solubility}

Solubility was analyzed by following Haque et al. (2012) method. Whatman no.1 filter paper and centrifuge tubes were placed in an oven at $105^{\circ} \mathrm{C}$ for 1 hour. Filter paper (A) and centrifuge tube (B) were then weighed. Samples were taken as much as

$$
\begin{array}{ll}
\phi & =\text { Oil fraction volume } \\
\mathrm{C} & =\text { Sample concentration }\left(\mathrm{gram} / \mathrm{m}^{3}\right)
\end{array}
$$

$6 \mathrm{~mL}$ and stirred for $30 \mathrm{~min}$, added in a centrifuge tube and centrifuged for $10 \mathrm{~min}$ at $400 \mathrm{rpm}$. The supernatant was filtered by using filter paper and a precipitate was obtained in a centrifuge tube and filtered. Filter paper with solid samples and centrifuge tubes along with precipitated 
were then placed in an oven at $105^{\circ} \mathrm{C}$ for $24 \mathrm{~h}$ and then the centrifuge tube $\left(\mathrm{B}^{\prime}\right)$ is weighed again. Solubility testing is calculated by the following formula:

Description:

$\mathrm{A}=$ Initial weight of the

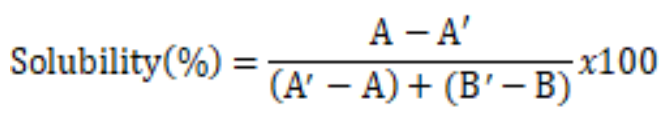

$A^{\prime}=$ Weight of the filter paper and sample after taken from the oven

filter paper

$\mathrm{B}=$ Initial weight of the centrifuge tube

$\mathrm{B}^{\prime}=$ Weight of the centrifuge tube and sample after taken from the oven

\section{Foaming capacity}

The foaming capacity was analyzed

by following Al-Awwaly et al. (2015) method with modification. Fifty $\mathrm{mL}$ of the sample is prepared in advance and the initial volume is recorded (Vi). After that, the sample is homogenized by using a hand mixer (BOSCH) for $1 \mathrm{~min}$ under room temperature and the resulting volume is recorded as the final volume (Vf). The foaming is calculated by the following formula:
Description:

$\mathrm{Vi}=$ Original volume of the

$$
\text { Foaming capacity }(\%)=\frac{V_{f} x V_{i}}{V_{i}} x 100
$$

$\mathrm{Vf}=$ Total volume of the sample after whipping

\section{Sedimentation}

Sedimentation analysis was carried out by using Airoldi et al. (2007) method which explains that the test was carried out by preparing a filter paper in the oven at a temperature of $105^{\circ} \mathrm{C}$ for $1 \mathrm{~h}$ and then sample before whipping

$$
\text { Sedimentation (\%) }=\frac{A}{B} x 100
$$

Description:

weighed A (grams). Five $\mathrm{mL}$ of the sample is taken and filtered by using filter paper. Filter paper is put in oven and sample solids at $105^{\circ} \mathrm{C}$ for $3 \mathrm{~h}$ then weighed with filter paper B $(\mathrm{g})$. Calculation of sedimentation uses the formula:

$A=$ Weight of the filter paper

$\mathrm{B}=$ Weight of the filter paper and sample after taken from the oven

\section{Data analysis}

The research data were analyzed by using analysis of variance (ANOVA) and then followed by the least significant difference test (LSD).

\section{RESULTS AND DISCUSSIONS}

Casein acts as a delivery system for bioactive compounds added to the product. This is necessary because the addition of catechins cannot be added directly to the product due to its vulnerability to high temperatures and the number of components in a material that will affect its interaction. The process of catechins addition in casein should be done through some analysis to find out the functional properties of casein which remain stable compared to control (casein without the addition of catechins).

\section{Emulsion stability}

The casein emulsion stability with different levels of catechin addition is presented in Table 1. The results of the analysis showed that the addition of catechins gave a significant difference $(\mathrm{P}<0.05)$ to the emulsion stability. The presence of bonds formed between proteins and phenolic compounds will affect the stability of the emulsion. This is in accordance with Rahayu et al. (2015) which 
explains that emulsion stability is an indication of interaction. This is also consistent with the research by Prommajak and Ravivan (2013) which showed that proteins that have been interacted with other compounds can produce higher emulsion compared to pure protein. The control treatment (P0) has an average emulsion index value of $93.297 \%$. This showed that there is a greater need for the size of the hydrophobic globules formed by $93.297 \%$. Casein has a consistent property with a fixed regulated emulsion solution in the absence of catechins.

These properties initiate steric hydrant reactions that able to form and produce emulsions at the interface that makes the layer. Interaction between $\beta$-casein globules can be used as creaming and flocculation, thus coalescence can be inhibited. The P1, P2, P3 and P4 treatments produce emulsion stability at $93.82 \%$ : $93.940 \%$ and $94.610 \%$. Based on these results casein has the ability to increase global hydrophobic size. This treatment is still able to maintain emulsion, even though the time of emulsion instability is faster than other treatments. Based on emulsion stability, it showed that the addition of catechins increases emulsion stability. This showed that casein-catechin solution formed an emulsion. The formation of emulsion system between catechins and casein is proportional to the smaller the size of the catechin or casein globules in the emulsion system and therefore the emulsions will be more stable. The substance accumulation at the interface area is called adsorption. In adsorption, the adsorbate is only present on the surface area, whereas, in absorption, adsorbate enters the adsorbent.

This is in accordance with the explanation made by Estiasih et al (2016) that adsorption can be defined as the absorption event of a substance on another surface. Substances that are absorbed are called adsorbates, while substances that absorb are called adsorbents. The interface region is a continuous phase region in direct contact with the dispersed phases which able to separate the two phases, either gas, liquid or solid.

The two phases have different types and properties of molecules. Molecules in the study sample experience pulling forces in various directions. However, at the interface, the dispersed phase molecule is attracted more strongly to the inside compared to the outside pulling force. This is in accordance with Estiasih et al (2016) who explains that a fluid consisting of two phases will try to minimize the interface area so that the dispersed phase globules will be spherical in shape to minimize interactions with the dispersing phase. Cohesion and adhesion forces play a role in the interface. Cohesion is a homogeneous attraction between molecules that is homogeneous, while adhesion is a heterogeneous attraction between molecules. Casein-catechin solutions have a greater cohesion force because the number of particles has more cohesion forces than adhesion forces, therefore, the solution an interface is formed. This is also in accordance with the explanation of Estiasih et al (2016) that if the cohesion force is greater than the adhesion then an interface formation occurs.

\section{Emulsion activity}

Emulsion activity is one of the determinants of emulsion properties that plays an important role in the quality of casein. Variance analysis results show that the treatment of catechins with different concentrations does not provide a significant difference $(\mathrm{P}>0.05)$ on the emulsion activity statistically. That is because the ability of casein as an emulsifier is capable to stabilize the mixed solution. This is in accordance with İbanoğlu and Karataş (2000) who explains that emulsifier molecules are adsorbed at the interface because they orient themselves with the hydrophilic part of water and the hydrophobic part of the oil. An emulsion is a liquid dispersion system in a liquid whose liquid molecules do not intermingle but are antagonistic to each other. In an emulsion there are usually three parts, including the dispersed part in the 
form of granules consisting of fat, the dispersing media part consisting of water, and the emulsifying part that serves to keep the oil droplets remaining dispersed in water.

Emulsion activity is affiliated with the ability of proteins to cover the oil-water interface (Anton and Gandener, 1997; Fox, 2003). Emulsion activity index calculation results show that the addition of catechins with different concentrations can increase the ability of casein to form emulsions. This is because casein can emulsify mixed solutions with catechin concentrations which correspond to the research treatment of $2 \%$. Supported by Estiasih et al (2016) who explains that the ability of the activity and stability of the emulsion depends on the pattern of distribution of hydrophobic and hydrophilic portions of the protein. The treatment without the addition of catechin solution ( $\mathrm{P}$ 0) had an average emulsion activity index value of 4,396 , while the treatment of adding catechins in the treatments P1, P2, P3, and P4 gave the results of the emulsion activity respectively of 6,$15 ; 6,69 ; 7,08$ and 7,58. This showed that the catechin solution is hydrophilic therefore it affects the ability of casein to form emulsions. This also showed that casein is amphiphilic and capable to form emulsions spontaneously. Casein has hydrophobic and hydrophilic groups in which $\alpha$-casein is hydrophilic, $\beta$-casein is more hydrophobic than $\alpha$-casein and $\mathrm{K}$ casein. This is because the $\beta$-casein group contains more proline (Livney, 2010). Casein micelles are colloids with a diameter of 50-500 nm (1 nm = $1 \times 10-6 \mathrm{~mm})$ (Fox, 2003). Casein is composed of 3 molecules namely $\alpha$-casein, $\beta$-casein and $\mathrm{K}$-casein in a ratio of 5: 4: 1 (Swaisgood, 2003).

Table 1. Functional properties of casein and casein added with catechin

\begin{tabular}{cccccc}
\hline Catechin (\%) & $\begin{array}{c}\text { Emulsion } \\
\text { stability } \\
(\%)\end{array}$ & $\begin{array}{c}\text { Emulsion } \\
\text { activity } \\
\mathrm{m}^{2} / \mathrm{g}\end{array}$ & $\begin{array}{c}\text { Solubility } \\
(\%)\end{array}$ & $\begin{array}{c}\text { Foaming } \\
\text { capacity } \\
(\%)\end{array}$ & $\begin{array}{c}\text { Sedimentation } \\
(\%)\end{array}$ \\
\hline 0 (control) & $93.30^{\mathrm{a}} \pm 1.00$ & $4.40^{\mathrm{a}} \pm 0.25$ & $88.36^{\mathrm{a}} \pm 1.84$ & $49.67^{\mathrm{a}} \pm 2.08$ & $0.038^{\mathrm{d}} \pm 0.005$ \\
0.5 & $93.82^{\mathrm{a}} \pm 0.19$ & $6.15^{\mathrm{a}} \pm 0.87$ & $89.12^{\mathrm{a}} \pm 0.48$ & $53.33^{\mathrm{b}} \pm 0.58$ & $0.037^{\mathrm{cd}^{\mathrm{d}}} \pm 0.005$ \\
1.0 & $93.94^{\mathrm{a}} \pm 0.31$ & $6.69^{\mathrm{a}} \pm 0.44$ & $88.65^{\mathrm{a}} \pm 0.61$ & $56.00^{\mathrm{c}} \pm 1.00$ & $0.035^{\mathrm{bc}} \pm 0.001$ \\
1.5 & $94.61^{\mathrm{b}} \pm 0.22$ & $7.10^{\mathrm{a}} \pm 0.79$ & $88.39^{\mathrm{a}} \pm 0.59$ & $57.67^{\mathrm{c}} \pm 0.58$ & $0.034^{\mathrm{b}} \pm 0.001$ \\
2.0 & $95.16^{\mathrm{b}} \pm 0.22$ & $7.58^{\mathrm{a}} \pm 1.59$ & $89.04^{\mathrm{a}} \pm 0.66$ & $58.00^{\mathrm{c}} \pm 1.00$ & $0.033^{\mathrm{a}} \pm 0.001$ \\
\hline
\end{tabular}

Different superscripts in the same column indicate a highly significant effect $(\mathrm{P}<0.05)$. Data are shown as mean \pm SD.

\section{Solubility}

The results of the variance analysis in Table 1 showed that the addition of catechins with concentrations did not give a significant difference in effect $(\mathrm{P}<0.05)$ on the solubility of casein. This can be caused by differences in concentration that are too small so that the interaction of the results that occur is not so visible on the solubility. This is supported by Gallo et al. (2013) explanation that milk protein can bind to catechin compounds which provides a more stable protein structure. The higher concentration of catechins can increase the solubility. Protein denaturation can be seen from changes in the physical structure of the protein that opens the folds in certain parts. The denatured protein decreases solubility. In addition, denatured proteins will decrease their solubility. It happened because the molecular layer on the hydrophobic side will change its position from the inside out, and vice versa. Thus, the condition will change solubility. The addition of catechins results in an increase in the average increase in solubility. Sumardjo (2008) explains that protein denaturation is the change of protein molecules to the secondary, tertiary and quaternary structure of protein molecules without breaking covalent bonds. Denaturation can also be interpreted as the process of breaking hydrogen bonds, 
hydrophobic interactions, salt bonds and folds of open protein molecules. The $2 \%$ catechin addition (P4) showed the best solubility.

The high solubility indicates an interaction between casein and catechins through hydrophobic interactions, van der Waals, hydrogen bonds, and ionic interactions that cause the solubility to increase. Zhou et al. (2015) state that catechins interact with casein because milk protein contains proline and has an open structure. Added by Jakobek (2015) that the interactions that occur between milk protein with catechins include hydrophobic interactions with non-covalent properties and hydrogen bonds as stabilizers of these bonds. The addition of catechins produces an average yield of solubility which tends to increase.

\section{Foaming capacity}

Variance analysis results Table 1 showed that the treatment of different catechin concentrations had a significant effect $(\mathrm{P}<0.05)$ on foaming capacity. This showed that the addition of hydrophilic compounds will increase the production of froth. Estiasih et al (2016) explain that froth inhibitors are composed of hydrophobic substances. The inhibitor was able to damage the formation of casein-catechins and produce little froth. The more hydrophilic groups, the more foam produced. The bond between whey protein and gelatin increases the froth. The higher froth power produced explains that the bonds formed in the protein get stronger, creating froth. This is in accordance with Ali, et al. (2010) which explains that protein modification can improve the functional properties of protein, one of which is foam.

The result of the foaming capacity in Table 1 has increased with the addition of a catechin solution. Analysis tests using LSD show that the control (P0) produced the lowest foaming value compared to other treatments, having froth value of $50 \%$. This shows that $\mathrm{P} 0$ has ability to produce foam and increase its final volume by $50 \%$ more than its initial volume. That is because casein acts as an emulsifier in solution. Casein plays a role in foaming and stabilizing the solution. The casein shaking process will cause unfolding of the structure so that the hydrophobic side of casein ( $\beta$ casein) will be exposed and interactions with air trapped during foaming will occur. The hydrophilic group will interact with $\alpha$ casein. The treatment of P4 with a concentration of the addition of catechins as much as $2 \%$ produces the highest foaming capacity by $58 \%$. This showed that the ability to produce foam gets better along with the increased concentration of catechins given. This is because the hydrophilic group formed by the addition of catechins more compared to the control.

\section{Sedimentation}

The data and analysis of variance in Table 1 show that the treatment of the addition of catechins with different concentrations gives a significant difference in effect $(\mathrm{P}<0.05)$ on the sedimentation value. The slight sedimentation value refers to the solubility value of casein. Interactions formed between casein and catechins can stabilize the structure of the protein so that the resulting sediment is small. Sediment formed is caused by several factors that cause casein micelles to separate from the bonds formed inside. Separation of casein micelles occurs during the phases of bonding of the calcium phosphate acid inter caseinate complex, formation of soluble casein complexity units, and disruption of hydrogen or hydrophobic bonds associated with soluble caseinate salts (monomers formation).

The average result of sedimentation value in the treatment decreases along with the higher percentage of catechins added. The decrease in sedimentation is thought to be due to the addition of more catechin concentrations which causes an increase in the bonds formed in stabilizing casein. The increase in protein- catechins bound is thought to increase as well as the solubility or solubility of the casein-catechin solution. 
According to Widodo et al. (2012), sediments are particles that are insoluble in water, consisting of denatured proteins, scorched or sticky particles, water-insoluble particles and the presence of additives. The P0 treatment is used as a control for the highest average sedimentation value compared to other treatments. This is thought to be due to the clot formed because of no binding compounds, thus reducing the solubility of its solubility and settles. The addition of catechins causes a decrease in the value of the resulting sedimentation. This is because catechins can interact with proteins, and casein contains proline with an open structure (Stojadinovic et al., 2013).

An open protein structure will cause interactions with other compounds. Catechins are polyphenol compounds that have the ability to bind and interact with casein to form a protein-polyphenol complex. According to Ye et al. (2013) interactions formed between catechins and milk proteins occur by forming catechinprotein complexes. Ferruzi et al. (2012) explain that the interactions formed between proteins and polyphenols were caused by hydrophobic interactions and hydrogen bonds in phenolic hydroxy groups. Hydrophobic interactions will form nonspecific peptide bonds so that proline and polyphenol will undergo conformational changes resulting in decreased solubility and sediment or sediment formation. The heating process can cause proteins that have not formed bonds with other compounds denatured. An increase in the percentage of catechins added to the solution will result in decreased sedimentation value.

\section{CONCLUSION}

This study showed that the catechin addition can improve the functional properties of casein on emulsions stability and reduce the formation of sedimentation. Based on these results, significant results were obtained on the addition of $2 \%$ catechins which showed emulsion stability at $95.160 \%$, emulsion activity at $7.581 \mathrm{~m}^{2} / \mathrm{g}$, foaming capacity at $58 \%$, solubility at $89.037 \%$ and sedimentation at $0.033 \%$.

\section{REFERENCES}

Airoldi, L., \& Beck, M. W. (2007). Loss, status and trends for coastal marine habitats of Europe. Oceanography and Marine Biology, 45, 345-405.

Al-Awwaly, K., Triatmojo, S., Artama, W., \& Erwanto, Y. (2015). Chemical Composition and some functional properties of beef lung protein concentrate extracted by alkaline method. Jurnal Ilmu Dan Teknologi Hasil Ternak, 10(2), 54-62. https:// doi.org/10.21776/ub.jitek.2015.010.02.6

Ali, F., Ranneh, Y., Ismail, A., \& Esa, N. M. (2015). Identification of phenolic compounds in polyphenols-rich extract of Malaysian cocoa powder using the HPLC-UV-ESI-MS/MS and probing their antioxidant properties. Journal of Food Science and Technology, 52(4), 2103-2111. https://doi.org/10.1007/s13197-013-1187-4

Ali, N. A., Ahmed, S. H., Mohamed, E. A., Ahmed, I. A. M., \& Babiker, E. E. (2010). Effect of transglutaminase cross linking on the functional properties as a function of $\mathrm{NaCl}$ Concentration of legumes protein isolate. World Academy of Science, Engineering and Technology, 4, 910-915.

Anton, M., \& Gandemer, G. (1997). Composition, solubility and emulsifying properties of granules and plasma of egg yolk. Journal of Food Science, 62(3), 484-487. https: //doi.org/10.1111/j.1365-2621.1997.tb04411.x

Bonnaillie, L., Zhang, H., Akkurt, S., Yam, K., \& Tomasula, P. (2014). Casein films: the effects of formulation, environmental conditions and the addition of citric pectin on the 
structure and mechanical properties. Polymers, 6(7), 1-19. https://doi.org/ 10.3390/polym6072018

Estiasih, T., Harijono, Waziiroh, E., \& Fibrianto, K. (2016). Kimia dan Fisik Pangan. Jakarta: Bumi Aksara.

Ferruzzi, M. G., Bordenave, N., \& Hamaker, B. R. (2012). Does flavor impact function? Potential consequences of polyphenol-protein interactions in delivery and bioactivity of flavan-3ols from foods. Physiology \& Behavior, 107(4), 591-597. https:// doi.org/10.1016/j.physbeh.2012.02.020

Fox, R., \& McDonald, A. (2003). Introduction to Fluid Mechanics. New York: John Wiley \& Sons Inc.

Gallo, M., Vinci, G., Graziani, G., De Simone, C., \& Ferranti, P. (2013). The interaction of cocoa polyphenols with milk proteins studied by proteomic techniques. Food Research International, 54(1), 406-415. https:// doi.org/10.1016/J.FOODRES.2013.07.011

Giroux, H. J., Robitaille, G., \& Britten, M. (2016). Controlled release of caseinderived peptides in the gastrointestinal environment by encapsulation in water-in-oil-in-water double emulsions. LWT - Food Science and Technology, 69, 225-232. https:// doi.org/10.1016/J.LWT.2016.01.050

Haque, E., Whittaker, A. K., Gidley, M. J., Deeth, H. C., Fibrianto, K., \& Bhandari, B. R. (2012). Kinetics of enthalpy relaxation of milk protein concentrate powder upon ageing and its effect on solubility. Food Chemistry, 134(3), 1368-1373. https:// doi.org/10.1016/j.foodchem.2012.03.034

İbanoğlu, E., \& Karataş, Ş. (2001). High pressure effect on foaming behaviour of whey protein isolate. Journal of
Food Engineering, 47(1), 31-36. https://doiorg/10.1016/S0260-8774(00)00096-0

Jakobek, L. (2015). Interactions of polyphenols with carbohydrates, lipids and proteins. Food Chemistry, 175, 556-567. https://doi.org/10.1016 /j.foodchem.2014.12.013

Jalil, A., \& Ismail, A. (2008). Polyphenols in cocoa and cocoa products: is there a link between antioxidant properties and health. Molecules, 13(9), 21902219. https://doi.org/10.3390/molecu les 13092190

Lemes, U., Sandra, S., Decker, E. A., \& McClements, D. J. (2010). Impact of surface deposition of lactoferrin oh physical and chemical stability of omega-3 rich lipid droplets stabilised by caseinate. Food Chemistry, 123(1), 99-106.

Livney, Y. D. (2010). Milk proteins as vehicles for bioactives. Current Opinion in Colloid \& Interface Science, 15(1-2), 73-83. https://doi. org/10.1016/J.COCIS.2009.11.002

McClements, D., Decker, E., \& Weiss, J. (2007). Emulsion-based delivery systems for lipophilic bioactive components. Journal of Food Science, 72(8), 109-124. https://doi.org/10.11 11/j.1750-3841.2007.00507.x

O'Connell, J. E., \& Fox, P. F. (2001). HeatInduced Coagulation of Milk. In P. F. Fox \& P. L. H. McSweeney (Eds.), Advanced Dairy Chemistry (3rd ed., pp. 879-945). New York, NY: KluwerAcademic/Plenum Publishers.

Prommajak, T., \& Raviyan, P. (2017). Physical properties of gelatin extracted from skin of Thai panga fish (Pangasius bocourti Sauvage). Food and Applied Bioscience Journal, 1(3), 131-145. 
Rahayu, P., Purwadi, P., Radiati, L., \& Manab, A. (2015). Physico chemical properties of whey protein and gelatine biopolymer using tea leaf extract as crosslink materials. Current Research in Nutrition and Food Science Journal, 3(3), 224-236. https://doi.org/10.12944/CRNFSJ.3.3.06

Ranadheera, C., Liyanaarachchi, W., Chandrapala, J., Dissanayake, M., \& Vasiljevic, T. (2016). Utilizing unique properties of caseins and the casein micelle for delivery of sensitive food ingredients and bioactives. Trends in Food Science \& Technology, 57, 178187. https://doi.org/10.1016/J.TIFS. 2016.10.005

Rusconi, M., \& Conti, A. (2010). Theobroma Cocoa L., the Food of the Gods: A scientific approach beyond myths and claims. Pharmacological Research, 61(1), 5-13. https://doi.org/ 10.1016/j.phrs.2009.08.008

Sablovic, M. B., Brncic, S. R., \& Lelas, V. (2013). Emulsifying Properties of TribomechanicallyTreated Whey Proteins. Journal of Food Technology, 63(2), 64-71.

Shahidi, F., \& Miraliakbari, H. (2005). Omega-3 fatty acids in health and disease: part 2-health effects of omega-3 fatty acids in autoimmune diseases, mental health, and gene expression. Journal of Medicinal Food, 8(2), 133-148. https://doi.org/ 10.1089/jmf.2005.8.133

Stojadinovic, M., Radosavljevic, J., Ognjenovic, J., Vesic, J., Prodic, I., Stanic-Vucinic, D., \& Cirkovic Velickovic, T. (2013). Binding affinity between dietary polyphenols and $\beta$ - lactoglobulin negatively correlates with the protein susceptibility to digestion and total antioxidant activity of complexes formed. Food Chemistry, 136(3-4), 1263-1271. https://doi.org/10.1016/J. FOODCHEM.2012.09.040

Strauss, G., \& Gibson, S. M. (2004). Plant phenolics as cross-linkers of gelatin gels and gelatin-based coacervates for use as food ingredients. Food Hydrocolloids, 18(1), 81-89. https:// doi.org/10.1016/S0268-005X(03)000 45-6

Sumardjo, D. (2008). Pengantar Kimia Buku Panduan Kuliah Mahasiswa Kedokteran. Jakarta: Buku Kedokteran EGC.

Swaisgood, H. E. (2003). Chemistry of the Caseins Advanced Dairy Chemistry. New York: Plenum Publishers.

Widodo, Viyunnur Rachmawati, A., Chulaila, R., \& Suparta Budisatria, I. G. (2012). Produksi dan evaluasi kualitas susu bubuk asal kambing peranakan ettawa (PE). Jurnal Teknologi Dan Industri Pangan, 23(2), 132-139. https://doi.org/10.60 66/jtip.2012.23.2.132

Ye, J., Fan, F., Xu, X., \& Liang, Y. (2013). Interactions of black and green tea polyphenols with whole milk. Food Research International, 53(1), 449-455. https://doi.org/10.1016/J.FOODRES.20 13.05.033

Zhou, S., Seo, S., Alli, I., \& Chang, Y.-W. (2015). Interactions of caseins with phenolic acids found in chocolate. Food Research International, 74, 177184. https://doi.org/10.1016/J.FOODRE S.2015.05.006 